\title{
Characterization of Chrysophyllum albidum and Anacardium occidentale gums as wet and dry binders in ciprofloxacin tablets
}

\author{
Ebere I OKOYE, Ifeoma NDIWE
}

\begin{abstract}
This study aimed to extract gums from Chrysophyllum albidum (CAG) fruit and Anacardium occidentale (AOG) bark tears; and characterize them as wet and dry binders in tablets. AOG and CAG were extracted using old and modified protocols respectively. CAG, polyvinylpyrrolidone (PVP) and gelatin (GTN) were used in wet granulation (WG), while CAG, AOG, pregelatinized starch (PGS) and hydroxypropylmethyl cellulose (HPMC) were used in direct compression (DC). Granules and powder blends were evaluated for flowability, while tablets underwent standard quality assessment to characterize and compare $\mathrm{CAG}$ and $\mathrm{AOG}$ to standard binders. CAG yield was influenced by anti-solvent and procedure used. Ethanol precipitated more gum than acetone; slurry from mixture of exocarp and mesocarp gave lower gum yield than mesocarp alone. On flowability, granules formulated with CAG flowed
\end{abstract}

better than those containing PVP or GTN. Ciprofloxacinexcipients blends exhibited poor flow but can be rank in order of performance: $\mathrm{PGS}>\mathrm{AOG}>\mathrm{CAG}>\mathrm{HPMC}$. WG tablets possessed excellent mechanical properties, with binder efficiency ranked as: $\mathrm{CAG}>\mathrm{PVP}>\mathrm{GTN}$. DC tablets had acceptable mechanical properties (CAG at concentrations $\geq 6 \%$, AOG at $\geq 2 \%$ ). Drug release from WG with CAG or PVP at $1-2 \%$ was $\geq 80 \%$ in 30 min, but CAG significantly $(\mathrm{p}<0.05)$ reduced release at $3-4 \%$, while GTN did at $2-4 \%$. DC tablets (CAG or PGS) released $\geq$ $80 \%$ drug in $30 \mathrm{~min}$. AOG imparted slow release, while HPMC allowed much slower release. CAG and AOG have good binder efficiencies, thus useable at low concentrations as wet and dry binders to produce tablets with acceptable pharmaceutical characteristics.

Keywords: Chrysophyllum albidum gum, Anacardium occidentale gum, wet and dry binders, ciprofloxacin tablets.
Ebere I Okoye

Department of Pharmaceutics and Pharmaceutical Technology, Faculty of Pharmaceutical Sciences, Nnamdi Azikiwe University, Awka, Anambra State, Nigeria

Ifeoma Ndiwe

Department of Pharmaceutical Technology, Faculty of Pharmacy, Madonna University, Elele, Rivers State, Nigeria

Corresponding author: Ebere I Okoye

E-mail:ei.okoye@unizik.edu.ng

Tel: +234(0)8052742521

Submitted/Gönderilme: 01.01.2016 Accepted/Kabul: 11.03.2016

Revised/Düzeltme: 07.03.2016

\section{INTRODUCTION}

Tablets are solid dosage forms produced by compacting of powders or granules using relatively high pressures from punches within a confined space known as die in a tableting machine. They are the most popular and versatile dosage forms in pharmaceutical care services and can be designed to achieve diverse drug delivery systems $(1,2)$. One of the most important ingredients incorporated in powder/granule mix during production processes is the binder, which imparts cohesiveness on the powders/granules.

Chrysophyllum albidum (Linn) is ordinarily known as African star apple, udara (Igbo language), agbalumo (Yoruba language) in Nigeria. It is also indigenous in other African countries like: Niger, Uganda, Cote d' Ivore and Cameroon. Chrysophyllum albidum is one of the eighty species of the 
family Sapotaceae (3). In Nigeria it is widely spread in lowland tropical rain forests. It begins to fruit by the month of July and they ripen between December and March (4). The fruit is dark green in colour when unripe but turns into yellowish orange as it ripens (Figure 1) and when over ripe turns to rusty orange. The fruit is a berry which contains fleshy pulp and in most cases five hard seeds. The fleshy pulp of the fruit is eaten especially as snacks, while the exocarp is chewed by some to form stable chewing gum. This fruit belongs to the class of raw materials that are generally regarded as safe for the production of food and pharmaceuticals for human and animal consumption. Typical of agricultural produce in Africa, poor storage of Chrysophyllum albidum fruit leads to a lot of wastages that are very obvious on inspection of refuse dump sites and markets in Nigeria during the ripening season of the fruit $(5,6)$. This fruit apart from its food and nutraceutical properties may therefore be harnessed for pharmaceutical excipient purposes by indigenous industries to further improve its economic value, stop the wastages that are currently prevalent and encourage large scale farming of the plant and this will be a source of employment for the teaming youths of West Africa.

Anacardium occidentale gum on the other hand has been extensively studied for its use in the food industry as well as a pharmaceutical excipient (7-12), but no study has evaluated its characteristics as a dry binder in tablets. The need to evaluate this is paramount since many manufacturers prefer the direct compression tablet production process to wet granulation because of obvious advantages (13).

Ciprofloxacin is a second generation fluoroquinolone antibiotic useful for the treatment of diverse bacterial infections including those caused by Gram-positive and Gram-negative bacteria $(14,15)$. It is a commonly prescribed drug for the treatment of typhoid fever, throat infections, bone infections, a component of the cocktail for tuberculosis treatment, used as surgical prophylaxis, etc. For this reason some indigenous pharmaceutical manufacturers produce its tablets and very many importers bring the tablets into many West African countries from India. The indigenous manufacturers complain of inability to compete with the low cost of the imported generics of ciprofloxacin tablets; and contributors to the high cost of locally manufactured products include importation of all excipients in addition to the active drug needed for the production of ciprofloxacin $\mathrm{HCl}$ tablets. It is common knowledge to those skilled in the art of tablet production that the process involves any one of: wet granulation, dry granulation (slugging) or direct compression. Many formulation scientists have studied the properties of ciprofloxacin tablets formulated using these processes (16-18). In this study, ciprofloxacin $\mathrm{HCl}$ powder was chosen as a model antibiotic with wide prescription characteristics and patronage (which stimulates the competition between indigenous manufacturers and importers). The purpose of this study was therefore to employ common production processes (i.e. wet granulation and direct compression) available to indigenous pharmaceutical manufacturers and examine the possibility of formulating good ciprofloxacin tablets using raw materials from indigenous food sources whose safety profiles are excellent. This was undertaken by characterizing the binding properties of gums from Chrysophyllum albidum fruit and Anacardium occidentale bark exudate as wet and dry adhesive excipients in ciprofloxacin powder using some Pharmacopeial grade adhesive excipients as comparators.
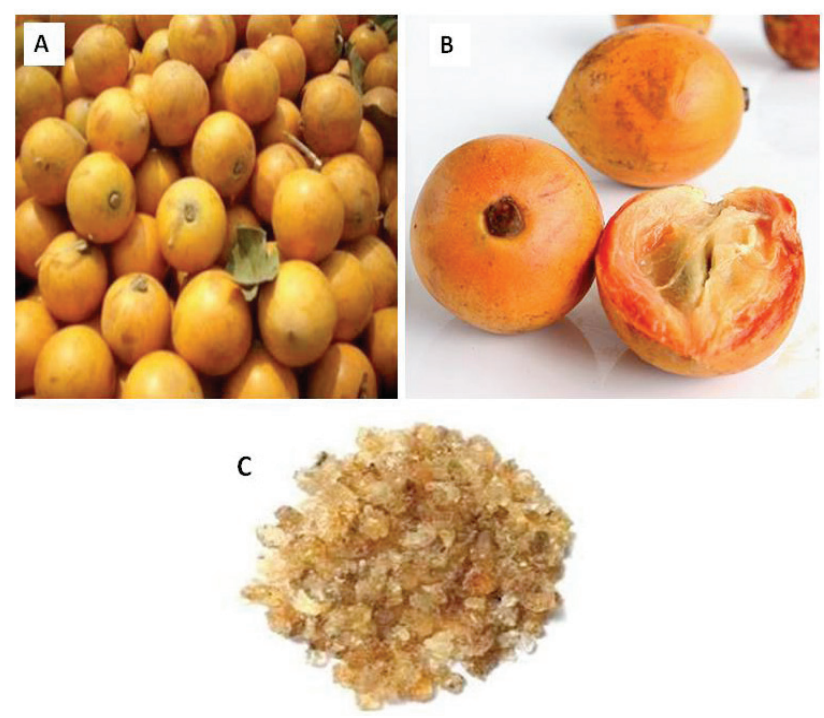

Figure 1. Raw materials for binder extraction-A: ripe fruit of Crysophyllum albidum; B: opened ripe fruit showing the pulp/ mesocarp; C: Anacardium occidentale dry exudates (5-6).

\section{MATERIALS AND METHOD}

\subsection{Materials}

The materials included: ciprofloxacin powder (a gift from Juhel Pharma. Nigeria), corn starch BP, ethanol (95\%), acetone, gelatin, polyvinyl pyrrolidone (PVP), hydroxypropyl methyl cellulose (HMPC) (all from Sigma-Aldrich, Germany); partially pregelatinized starch, generated from Corn starch B.P. (Sigma-Aldrich, Germany) by BPC (1979) method (19), cashew gum was extracted using the method reported by Okoye et al., (2012) (20), Chrysophyllum albidum gum was extracted from ripe fruits. Other reagents were of analytical grade and water was double distilled. 


\subsection{Methods}

\subsubsection{Exatraction of Chrysophyllum albidum gum}

The Chrysophyllum albidum fruits were purchased from Ose Okweodu market in Onitsha, Anambra State, Nigeria; authenticated by Prof B.A. Ayinde of the University of Benin and Nnamdi Azikiwe University (UNIZIK) Awka, and a sample was deposited in the herbarium of Department of Pharmacognosy and Traditional Medicine UNIZIK with the voucher specimen number: PCG474/A/019 attached. The seeds were removed, and two preliminary processes were undertaken to determine how best to extract the gum. In the first process, $100 \mathrm{~g}$ of the exocarp with mesocarp were milled in the presence of $200 \mathrm{ml}$ of distilled water using a blender (Panasonic MX 337N, Japan). The resulting slurry was made up to $1000 \mathrm{ml}$ with distilled water and allowed to stand for $24 \mathrm{~h}$ with intermittent stirring. Thereafter, the mixture was strained using muslin cloth and the mucilage was divided into two equal parts and one portion was precipitated by mixing it with three times its volume of ethanol, while the second with acetone. The suspension of the precipitated gum was centrifuged (Techmel and Techmel, USA) at 3000 $\mathrm{g}$ for $15 \mathrm{~min}$ and the gum was harvested after decanting the supernatant. In the second process, the exocarp was removed and $100 \mathrm{~g}$ of mesocarp was subjected to the extraction procedure above. The precipitated 'gums' from the four different 'mucilages' were harvested and soaked in the precipitating anti-solvent for $8 \mathrm{~h}$ in order to cause removal of entrapped water. They were thereafter air dried and heated in a hot air oven (Ceword medical equipment, England) at $60^{\circ} \mathrm{C}$ for $1 \mathrm{~h}$. These procedures were repeated twice using acetone or ethanol, the percentage yields of the 'gums' were evaluated and the results were used to determine the method most suitable for Chrysophyllum albidum gum extraction. After extraction and drying of the gum, it was milled with the blender, screened through $150 \mu \mathrm{m}$ sieve and stored in air tight container over silica gel.

\subsubsection{Granulation of ciprofloxacin powder}

Fifty grams (50 g) of ciprofloxacin powder was mixed with the relevant amount of corn starch BP (Table 1) using mortar and pestle. The powder mix was then moistened with $10 \mathrm{ml}$ of binder (Chrysophyllum albidum gum-CAG, polyvinylpyrrolidone-PVP or gelatin-GTN) solution: 6.0, $11.5,16.9$ and $22.5 \% \mathrm{w} / \mathrm{v}$ binder in water that was equivalent to $1.0,2.0,3.0$ and $4.0 \% \mathrm{w} / \mathrm{w}$ concentration of binder in the granules (Table 1). The mixture was kneaded with pestle to form a damp mass, which was screened using a sieve of aperture size $1000 \mu \mathrm{m}$ and dried in the oven at $60^{\circ} \mathrm{C}$ for $1 \mathrm{~h}$. The dried granules were screened using a sieve of aperture size $600 \mu \mathrm{m}$, dried again at $60^{\circ} \mathrm{C}$ for $1 \mathrm{~h}$. Thereafter, the granules were packed in air tight containers over silica gel.

\subsubsection{Blending of ciprofloxacin powder and excipients for direct compression}

Each powder was screened through $150 \mu \mathrm{m}$ sieve before use. Fifty grams (50 g) of ciprofloxacin powder was mixed with relevant amounts of binder (CAG, AOG, PGS or HPMC) and disintegrant (corn starch BP) (Table 1) and blended for 15 min using a bench top planetary mixer (Kenwood, model OWHM400020, Japan). The blended powders were packed in air tight containers over silica gel.

\subsubsection{Granule/powder flowability characterization}

Twenty grams (20 g) of granules/powder mix were used to determine bulk density, tapped density, flow rate, angle of repose, Carr's index and Hausner's ratio by methods reported previously (21). Triplicate determinations were carried out for each parameter.

\subsubsection{Compaction of granules/powder blends into tablets}

Before compaction the granules or powder blends were mixed with $0.5 \% \mathrm{w} / \mathrm{w}$ of magnesium stearate for $5 \mathrm{~min}$ using a powder bottle. Tableting was carried out with a twelve station tablet press (JC - RT - 24H, Jenn Chiang Machinery Co., LTD, Feng - Yuan, Taiwan) equipped with $13 \mathrm{~mm}$ flat faced punches. The dies were set to contain volumes of granules/ powder blends weighing $590-610 \mathrm{mg}$, and compaction was done with a force of $15 \mathrm{KN}$. The resulting tablets were stored in airtight containers over silica gel for $72 \mathrm{~h}$ before tablet quality assessments on the tablets were conducted.

Table 1. Formulation ingredients and use level

\begin{tabular}{|c|c|}
\hline Ingredient & Amount per Tablet \\
\hline \multicolumn{2}{|c|}{ Wet Granulation } \\
\hline Ciprofloxacin & $500 \mathrm{mg}$ \\
\hline Binder (CAG, GTN or PVP) & $1,2,3,4 \% \mathrm{w} / \mathrm{w}$ \\
\hline $\begin{array}{l}\text { Disintegrant (Corn starch } \\
\text { BP) }\end{array}$ & $12.5 \% \mathrm{w} / \mathrm{w}$ \\
\hline Magnesium stearate & $0.5 \% \mathrm{w} / \mathrm{w}^{*}$ \\
\hline \multicolumn{2}{|c|}{ Direct Compression } \\
\hline Ciprofloxacin & $500 \mathrm{mg}$ \\
\hline $\begin{array}{l}\text { Binder (CAG, AOG, PGS or } \\
\text { HPMC) }\end{array}$ & $2,4,6,8 \% \mathrm{w} / \mathrm{w}$ \\
\hline $\begin{array}{l}\text { Disintegrant (Corn starch } \\
\text { BP) }\end{array}$ & $12.5 \% \mathrm{w} / \mathrm{w}$ \\
\hline Magnesium stearate & $0.5 \% \mathrm{w} / \mathrm{w}$ \\
\hline
\end{tabular}




\subsubsection{Quality assessment of ciprofloxacin tablets}

\subsubsection{Weight uniformity (22)}

Twenty tablets selected at random from each batch were individually weighed using the electronic balance (Mettler Toledo B154, Switzerland) to an accuracy of within $\pm 1 \mathrm{mg}$. The mean weight and percentage deviation from the mean for each tablet were calculated.

\subsubsection{Tablet dimensions}

Ten tablets were selected at random fromm each batch and their dimensions (diameter and thickness) were measured with Mitutoyo gauge (Model 10C - 1012 EB Japan) to within $\pm 0.01 \mathrm{~mm}$.

\subsubsection{Tablet hardness (22)}

The hardness values of ten tablets selected at random from each batch were determined at room temperature $\left(35 \pm 2^{\circ} \mathrm{C}\right)$ by diametral compression using Eweka hardness tester (Karl Kolb, Erweka Germany). Results were taken from tablets that split cleanly into two halves without any sign of lamination.

\subsubsection{Tablet friability (23)}

The percentage friabilities of ten tablets selected at random from each batch were determined using Roche Friabilator (Copley/Erweka, Type, TAR 20, GMBH Germany), operated at $25 \mathrm{rpm}$ for $4 \mathrm{~min}$ and evaluated with the equation:

Friability $=\frac{\text { Initial tablets weight }- \text { Final tablets weight }}{\text { Initial tablets weight }} \times 100 \ldots$ (1)

\subsubsection{Disintegration time (23)}

The disintegration times of the tablets were determined in distilled water at $37 \pm 0.5^{\circ} \mathrm{C}$ using the disintegration tester (Manesty, Model: MK 4, UK). Six tablets were selected at random from each batch and the machine operated till all the tablets disintegrated. The results reported are the means \pm standard deviations.

\subsubsection{Binder efficiency (24)}

This was evaluated using tablet hardness, friability and disintegration time values according to the relationship:

Binder efficiency $=\frac{\text { Tablet hardness }}{\text { Friability }} \times \frac{1}{\text { Disintegration time }} \ldots$

\subsubsection{Dissolution study on ciprofloxacin tablets}

Dissolution test was carried out according to USP XXIII basket method with an eight chambered dissolution test machine (Erweka Germany Type: DT 80) operated at $50 \mathrm{rpm}$ for $60 \mathrm{~min}$ in $900 \mathrm{ml}$ of $0.1 \mathrm{~N} \mathrm{HCl}$ maintained at $37 \pm 0.5^{\circ} \mathrm{C}$.
Five millilitre $(5 \mathrm{ml})$ of dissolution fluid was withdrawn and replaced with $5 \mathrm{ml}$ of fresh medium at $5 \mathrm{~min}$ intervals. Each withdrawn sample was made up to $20 \mathrm{ml}$ with fresh medium, filtered and its absorbance determined with UV - Visible spectrophotometer (UV- 160A Shimadzu Corporation Japan) at $277 \mathrm{~nm}$ using $0.1 \mathrm{~N} \mathrm{HCl}$ as blank. Triplicate determinations were conducted and the mean values used to evaluate the percentage drug released by applying the calibration curve regression equation: $y=0.0114 x+0.0289$; $\mathrm{r}^{2}=0.9968$.

\subsection{Statistical analysis}

Graphing and regression analyses were performed with Graphpad Prism 5 (GraphPad Prism software Inc., 2012 San Diego, California, USA) while analysis of the results of various parameters tested was performed using one-way analysis of variance in Excel statistical package 2007. Significant differences were defined by $P<0.05$.

\section{RESULTS AND DISCUSSION}

\subsection{Gum yield}

Gum yield was influenced by anti-solvent and procedure used. Ethanol precipitated more gum than acetone; and extraction using both exocarp and mesocarp gave lower gum yield compared to yield when mesocarp alone was used. Quantitatively, precipitating mucilage from exocarp and mesocarp slurry with ethanol gave $25.11 \pm 3.22 \%$, whereas with acetone yielded $16.20 \pm 2.68 \%$ gum. Mucilage from mesocarp slurry precipitated with ethanol gave $34.12 \pm 4.41 \%$ and with acetone gum yield was $19.63 \pm 5.86 \%$. It was observed during extraction that when the exocarp and mesocarp were milled together, solid insoluble gum was present in the slurry prior to straining through the muslin cloth. In addition, the gum resulting from precipitation with acetone was dark brown in colour while that from ethanol was light brown in colour. The coloration may be attributed to oxidation during the drying process, implying that acetone encouraged more oxidation than ethanol, hence the deeper browning of its product. These observations have been documented previously for other polysaccharide gums precipitated using different solvents/solvent systems $(25,26)$.

\subsection{Granule/powder blend flowability}

Granule/powder flowability characterization is a very important aspect of solid dosage form production process. This is because the indices give insight into the flow behaviour of the material(s) during tableting or capsule filling. The parameters commonly used include: Hausner's ratio, Carr's index, angle of repose and flow rate. Figure 2 
shows the flowability indices of ciprofloxacin granules, while Figure 3 shows those of ciprofloxacin-excipient powder blends. Hausner's ratio values for all the granules are less than 1.3 (Figure 2A), an indication of passable flow (27). From Figure $2 \mathrm{~A}$, it appears as if the flowability characteristics of all the granules are similar, however, other parameters were more discriminating. Carr's index and angle of repose reveal that generally, granules formulated with Chrysophyllum albidum gum (CAG) flowed better (lower values) than the ones formulated with polyvinylpyrrolidone (PVP) or gelatin (GTN) (Figure 2B and 2C). These results were contradicted by flow rate (Figure 2D), in which CAG containing granules flowed most poorly. This apparent contradiction may be accounted for by differences in moisture contents, granule shape, granule size and size distribution, granule density and surface charges, which are parameters that influence free flow more in comparison to conditions that operate during tapping experiments (28).

Flowability characteristics of ciprofloxacin-excipients blends were poor (Figure 3). This is not unexpected and could be attributed to the small particle size of the powders, which is one of the major challenges inherent in tablet/capsule production without prior granulation of powders (29). It is however obvious from Figure 3 that powder blends containing partially pregelatinized starch (PGS) displayed the best flowability characteristics, while those containing HPMC displayed the worst. CAG containing blends displayed poorer flow characteristics than blends that contained AOG. As stated earlier, these differences may be attributed to differences in particle size distribution, particle density, moisture content, surface charges on the particles etc of the powder blends $(28,30)$.
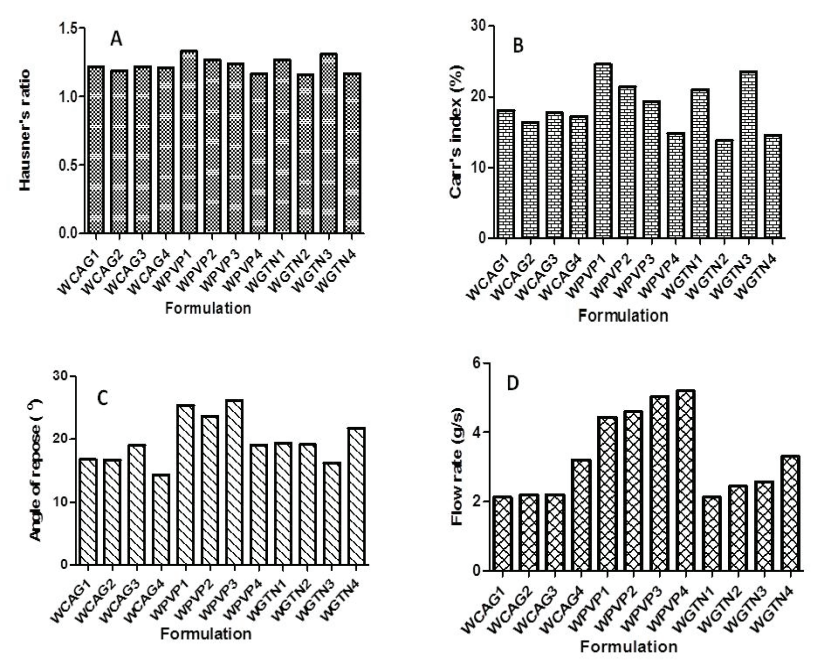

Figure 2. Flowability indices of ciprofloxacin granules
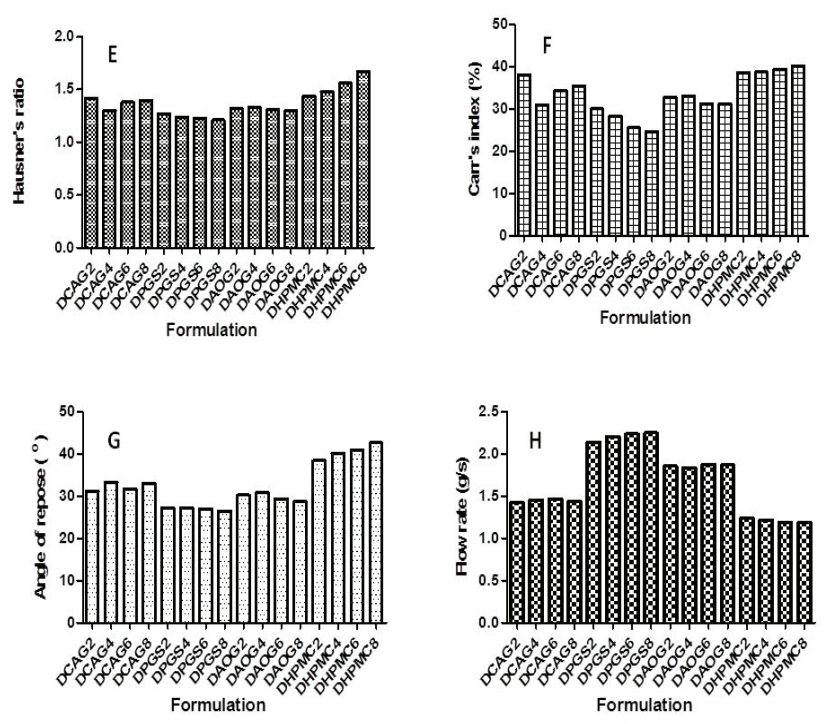

Figure 3. Flowability indices of ciprofloxacin-excipient powder blends

\subsection{Mechanical properties of tablets}

Tablet diameter and thickness are important quality assessment tests. Tablet diameter is solely determined and controlled by the diameters of the die and punch, as well as the robustness of the material used in fabricating them. Where the expansion of the die during compaction operations is negligible even in the presence of temperature rise as a result of friction, the diameters of tablets resulting from such an operation remains constant. The diameters of ciprofloxacin tablets produced in this study were virtually similar, with values in the range of $12.57 \pm 0.008 \mathrm{~mm}$ to $12.59 \pm 0.009 \mathrm{~mm}$. This suggests that the expansion of the die during tableting was indeed negligible, thus implying that the dies were fabricated with robust material. A rotary tablet press functions by compressing uniform volumes of powder that flow into the dies between two rollers using an upper and lower punch. In order to ensure the uniformity of the compression force and powder volume, the distance between the rollers is set prior to the compaction operation (31). Under the set conditions the tableting process ought to yield tablets of equal thicknesses. In practice however, due to vibrations that are inherent in the process, some variations may occur in powder volume fill, hence resulting in tablet weight and thickness variations. The thickness values for all the tablets ranged from $3.26 \pm 0.050$ $\mathrm{mm}$ to $3.42 \pm 0.080 \mathrm{~mm}$. Tablet thickness variation is required to be within $\pm 5 \%$ deviation from the mean (32), and all the batches of ciprofloxacin tablets produced met this requirement. Uniformity of tablet thickness is very important because it impacts on ease of automated tablet counting, tablet packaging using blisters or ordinary containers. 
All batches of tablets formulated by wet granulation technique possessed excellent mechanical properties (Table 2). Their friability values were all less than $1 \%$ and these may be related to their acceptable hardness values. Tablets disintegration time values were less than the conventional British Pharmacopeia recommendation of $15 \mathrm{~min}$ (33); and all the batches also met the requirement for tablet weight uniformity (34). Among the three binders, binder efficiency was of the order: CAG $>$ PVP $>$ GTN. Binder efficiency measures the interaction between tablet hardness, friability and disintegration time. A high binder efficiency implies that tablets formulated with it possess excellent hardness, low friability $(<<1 \%)$ and short disintegration time $(35,36)$.

Tablets produced by direct compression also possessed impressive mechanical properties. It was however observed that CAG could not reduce friability to $<1 \%$ until its content in the powder blend was $\geq 6 \% \mathrm{w} / \mathrm{w}$. AOG on the other hand demonstrated excellent dry binding ability, in that even at $2 \%$ $\mathrm{w} / \mathrm{w}$, it was able to reduce friability to $<1 \%$. PGS gave good tablets at content levels $\geq 4 \% \mathrm{w} / \mathrm{w}$, whereas HPMC which imparted excellent mechanical strength on tablets was nondisintegrating. All tablets from batches formulated with other gums disintegrated at much shorter time than the $15 \mathrm{~min}$ recommended for conventional tablets; and in addition were of acceptable weight uniformity (34). The binder efficiencies of the gums as dry binders were not impressive although they could be ranked in the order $\mathrm{CAG}>\mathrm{PGS}>\mathrm{AOG}>\mathrm{HPMC}$ (Table 2).

Table 2. Mechanical properties of ciprofloxacin tablets

\begin{tabular}{|c|c|c|c|c|c|}
\hline Formulation & Friability (\%) & $\begin{array}{c}\text { Weight } \\
\text { uniformity }^{*}\end{array}$ & $\begin{array}{l}\text { Disintegration time } \\
\text { (min) }\end{array}$ & $\begin{array}{l}\text { Hardness } \\
\left(\mathrm{Kg} / \mathrm{cm}^{2}\right)\end{array}$ & $\mathrm{BE}=\mathrm{H} / \mathrm{FD}$ \\
\hline \multicolumn{6}{|c|}{ Wet Granulation } \\
\hline WCAG1 & 0.930 & 2 & $1.240 \pm 0.181$ & $13.400 \pm 1.680$ & 11.620 \\
\hline WCAG2 & 0.074 & 2 & $1.400 \pm 0.205$ & $13.960 \pm 0.672$ & 134.749 \\
\hline WCAG3 & 0.068 & 1 & $1.640 \pm 0.374$ & $13.960 \pm 0.929$ & 116.212 \\
\hline WCAG4 & 0.035 & 0 & $2.540 \pm 1.134$ & $15.450 \pm 1.808$ & 173.791 \\
\hline WPVP1 & 0.480 & 2 & $1.100 \pm 0.072$ & $9.700 \pm 1.380$ & 18.371 \\
\hline WPVP2 & 0.370 & 2 & $2.010 \pm 0.707$ & $9.710 \pm 0.929$ & 13.056 \\
\hline WPVP3 & 0.330 & 2 & $2.840 \pm 1.055$ & $10.400 \pm 1.265$ & 11.097 \\
\hline WPVP4 & 0.290 & 1 & $4.340 \pm 1.162$ & $10.610 \pm 0.823$ & 8.430 \\
\hline WGTN1 & 0.670 & 2 & $1.130 \pm 0.070$ & $8.800 \pm 0.949$ & 11.623 \\
\hline WGTN2 & 0.530 & 1 & $3.530 \pm 0.455$ & $13.970 \pm 0.845$ & 7.467 \\
\hline WGTN3 & 0.380 & 1 & $4.420 \pm 0.366$ & $15.200 \pm 1.252$ & 9.050 \\
\hline WGTN4 & 0.270 & 0 & $6.150 \pm 0.466$ & $15.420 \pm 1.361$ & 9.286 \\
\hline \multicolumn{6}{|c|}{ Direct Compression } \\
\hline DCAG2 & 11.370 & 4 & $1.440 \pm 0.106$ & $12.050 \pm 1.926$ & 0.736 \\
\hline DCAG4 & 1.311 & 4 & $1.500 \pm 0.509$ & $14.450 \pm 0.865$ & 7.348 \\
\hline DCAG6 & 0.410 & 2 & $1.830 \pm 0.445$ & $16.710 \pm 0.684$ & 22.271 \\
\hline DCAG8 & 0.240 & 2 & $1.880 \pm 1.046$ & $17.040 \pm 0.636$ & 37.766 \\
\hline DPGS2 & 1.220 & 5 & $4.190 \pm 1.016$ & $14.580 \pm 0.798$ & 2.852 \\
\hline DPGS4 & 0.792 & 3 & $4.570 \pm 1.220$ & $15.480 \pm 0.653$ & 4.277 \\
\hline DPGS6 & 0.330 & 3 & $4.700 \pm 1.308$ & $17.800 \pm 0.516$ & 11.476 \\
\hline DPGS8 & 0.240 & 1 & $4.880 \pm 1.140$ & $18.120 \pm 0.270$ & 15.471 \\
\hline DAOG2 & 0.886 & 3 & $3.560 \pm 1.551$ & $14.170 \pm 3.496$ & 4.492 \\
\hline DAOG4 & 0.770 & 3 & $6.600 \pm 2.182$ & $14.440 \pm 2.887$ & 2.841 \\
\hline DAOG6 & 0.530 & 2 & $6.950 \pm 1.448$ & $14.780 \pm 2.594$ & 4.012 \\
\hline DAOG8 & 0.450 & 0 & $8.960 \pm 1.914$ & $16.200 \pm 2.013$ & 4.018 \\
\hline DHPMC2 & 0.055 & 4 & DND & $17.210 \pm 0.351$ & - \\
\hline DHPMC4 & 0.032 & 4 & DND & $17.800 \pm 0.432$ & - \\
\hline DHPMC6 & 0.230 & 5 & DND & $18.200 \pm 0.258$ & - \\
\hline DHРMC8 & 0.180 & 4 & DND & $18.340 \pm 0.366$ & - \\
\hline
\end{tabular}




\subsection{Dissolution characteristics of ciprofloxacin tablets}

Generally, the amount of drug released from tablets formulated by wet granulation decreased with increase in binder concentration (Figures 4). From Figure 4A and 4B, it is evident that for tablets formulated with CAG or PVP as wet binders, binder concentration increase from $1-4 \%$ $\mathrm{w} / \mathrm{w}$ while improving mechanical strength of tablets did not significantly retard drug release, in contrast to GTN which did (Figure 4C). Tablets formulated with CAG or PVP at $1-$ $2 \% \mathrm{w} / \mathrm{w}$ released $\geq 80 \%$ of ciprofloxacin in $30 \mathrm{~min}$, whereas GTN containing tablets (except WGTN1) did not meet this official requirement (37). At $3-4 \% \mathrm{w} / \mathrm{w}$ concentration CAG reduced drug release to amount significantly lower $(\mathrm{p}<0.05)$ than $80 \%$, unlike PVP which did so at $\geq 4 \% \mathrm{w} / \mathrm{w}$ (Figure 4A, 4B, 4F and 4G). This implies that utilization of $\mathrm{CAG}$ as wet binder in the formulation of water soluble drug for immediate release purposes may be limited to $\leq 2 \% \mathrm{w} / \mathrm{w}$ concentration in order to achieve adequate release of drug within a relatively short period, otherwise, drug release may be retarded.

Tablets formulated by direct compression using CAG or PGS met the requirement for $80 \%$ release of drug within $30 \mathrm{~min}$ (Figure 5). AOG imparted characteristic slow release on the drug even though the tablets disintegrated in less than 15 min (Figure 5I and Table 2). This may be attributed to the interaction between AOG and ciprofloxacin particles to form harder (more stable) crystals with lower aqueous solubility (38). HPMC on the other hand was completely non-disintegrating and drug release from its matrix was very slow (Figure $5 \mathrm{~K}$ ). This may be accounted for by the gel surrounding the dissolved drug and retarding the ingress of fresh dissolution fluid to elute dissolved drug (39). It is therefore note worthy that at concentrations $\geq 6 \% \mathrm{w} / \mathrm{w}$, CAG functioned satisfactorily as dry binder in ciprofloxacin tablets, just as PGS did, unlike AOG which gave tablets of satisfactory mechanical properties but unacceptable dissolution profile for conventional tablets.
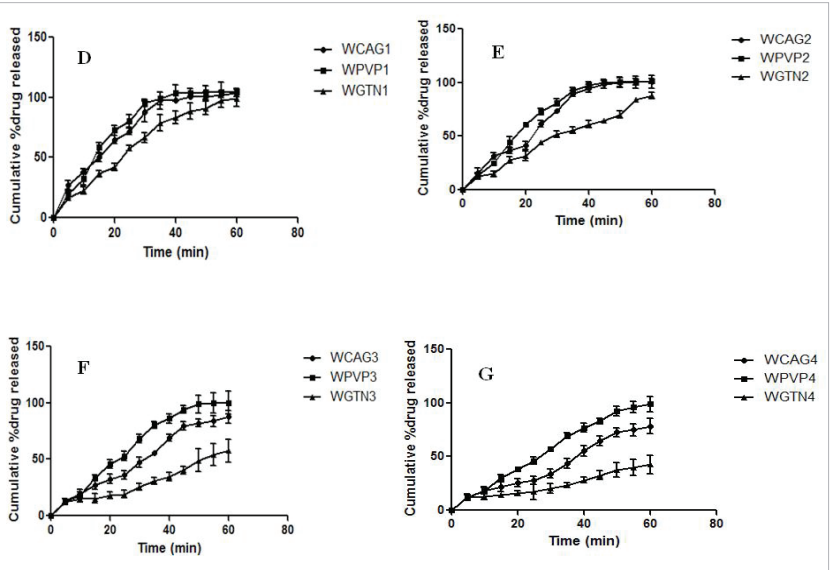

Figure 4. Dissolution profiles of ciprofloxacin tablets from wet granulation process (W) using binders: CAG (Chrysophyllum albidum gum), PVP (polyvinylpyrrolidone) and GTN (gelatin) at 1,2, 3 and $4 \% \mathrm{w} / \mathrm{w}$ concentrations
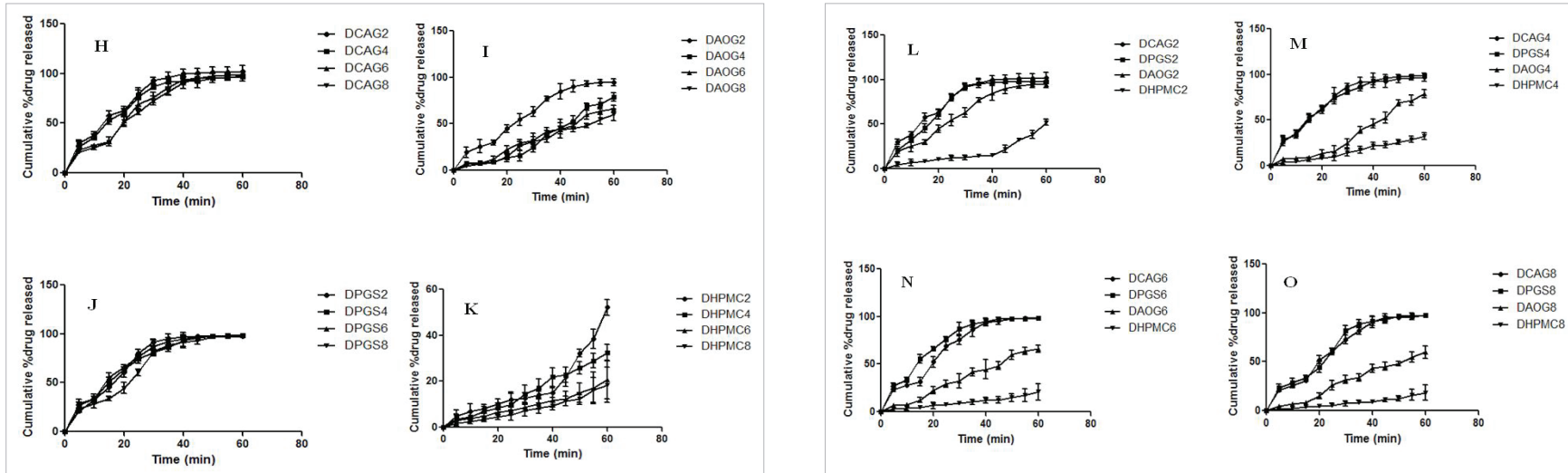

Figure 5. Dissolution profiles of ciprofloxacin tablets from direct compression process (D) using binders: CAG (Chrysophyllum albidum gum), AOG (Anacardium occidentale gum), PGS (partially pregelatinized starch) and HPMC (hydroxypropylmethyl cellulose) at 2, 4, 6 and $8 \% \mathrm{w} / \mathrm{w}$ concentrations. 


\section{CONCLUSION}

The evaluation of Chrysophyllum albidum and Anacardium occidentale gums as wet and dry binders in ciprofloxacin tablet formulations revealed marked differences in their characteristics as binding agents. As a wet binder, CAG has very high binder efficiency and may be employed at concentrations $\leq 2 \% \mathrm{w} / \mathrm{w}$ to produce tablets with acceptable mechanical and drug dissolution profile; while concentrations $\geq 6 \% \mathrm{w} / \mathrm{w}$ are required for its use in direct compression formulation purposes to produce satisfactory tablets. AOG on the other hand was investigated solely for dry binding application and from concentrations $\geq 4 \% \mathrm{w} / \mathrm{w}$ it depicted ability to retard drug release by a mechanism that needs further study.

Chrysophyllum albidum meyvelerinden ve Anacardium occidentale kabuk salgılarından elde edilen recinelerin siprofloksasin tablet formulasyonunda bağlayıcı olarak kullanılabilme ozelliklerinin değerlendirilmesi

ÖZ

$\mathrm{Bu}$ çalışmada Chrysophyllum albidum (CAG) meyvelerinden ve Anacardium occidentale (AOG) kabuk salgilarından elde edilen reçinelerin tablet formülasyonunda yaş ya da kuru granülasyonda bağlayıcı madde olarak kullanılabilme özellikleri üzerinde durulmuştur. AOG ve CAG, sırasıyla eski ve yeniden düzenlenmiş deney protokolleri kullanılarak tüketilmiştir. Yaş granülasyon yönteminde (WG), CAG, polivinilprolidon (PVP) ve jelatin (GTN) kullanılırken direkt basım yönteminde (DC), prejelatinize nişasta (PGS) ve hidroksipropilmetilsellüloz (HPMC) kullanılmıştır. Hazırlanan granüllerin ve toz karışımlarının akışkanlık özellikleri değerlendirilmiş, elde edilen tabletlere, CAG ve AOG'nin standart bağlayıcı maddelerle karşılaştırılması amacıyla standart kalite kontrol testleri uygulanmıştır. CAG veriminin anti-çözücü yaklaşımı ve kullanılan deneysel yöntemden etkilendiği tespit edilmiştir. Etanol kullanımının aseton kullanımına göre daha yüksek miktarda reçine çöktürdüğü, ekzokarp ve mezokarptan hareketle hazırlanan karışımlardan çöktürülen reçine

\section{ACKNOWLEDGEMENT}

The authors are grateful to Juhel Pharmaceuticals Nigeria Ltd for the provision of ciprofloxacin powder used in the study. We also salute Mr. Vitalis Amadi, the technologist in the Department of Pharmaceutical Technology, Madonna University Elele, who assisted in powder/ granule compaction; and Mr. Garba Abu of raw material and Pharmaceutical Technology Department of National Institute of Pharmaceutical Research and Development (NIPRD) Abuja, for his assistance with dissolution studies.

\section{CONFLICT OF INTEREST}

The authors declare no conflict of interest

miktarının mezokarptan hareketle çöktürülen miktardan daha düşük olduğu görülmüștür. CAG ile formüle edilen granüllerin akışkanlık özelliğinin PVP ve GTN içerenlere göre daha yüksek olduğu bulunmuştur. Siprofloksasin ve yardımcı maddelerin karışımı ile hazırlanan karışımın kötü akış özelliği göstermesine rağmen akış performansının $\mathrm{PGS}>\mathrm{AOG}>\mathrm{CAG}>\mathrm{HPMC}$ şeklinde olduğu görülmüştür. WG yöntemiyle hazırlanan tabletlerin mekanik özellikleri mükemmel olarak değerlendirilirken bağlayıcı etkinliğinin $\quad \mathrm{CAG}>\mathrm{PVP}>\mathrm{GTN}$ şeklinde olduğu görülmüştür. DC yöntemiyle hazırlanan tabletlerin mekanik özellikleri ise kabul edilebilir sınırlar içindedir (CAG için $\geq 6 \%$, AOG için $\geq 2 \%$ ). CAG veya PVP’nin \%1- 2 derişimde kullanıldığ 1 WG yöntemiyle hazırlanan tabletlerden ilaç salınımı 30 dakika içerisinde $\% \geq 80$ olarak bulunmuş ancak CAG'nin $(\mathrm{p}<0.05)$ ilaç salınımını \%3-4, GTN'nin ise \%2-4 oranında azalttığ görülmüştür. DC yöntemiyle hazırlanan tabletlerden (CAG veya $P G S$ ) ilaç salınımı 30 dakika içerisinde $\geq 80$ olarak tespit edilmiştir. AOG varlığında yavaş salınım gerçekleşirken, HPMC kullanıldığında salınımın daha da yavaş olduğu görülmüştür. CAG ve AOG'nin bağlayıcı özelliklerinin iyi olduğu ve kuru ya da yaş granülasyon yöntemiyle hazırlanacak tabletlerde düşük derişimde kullanıldıklarında kabul edilebilir sınırlar içerisinde farmasötik özelliklere sahip oldukları görülmüştür.

Anahtar kelimeler: Chrysophyllum albidum reçinesi, Anacardium occidentale reçinesi, yaş ve kuru granülasyonda kullanılan bağlayıcılar, siprofloksasin tablet

\section{REFERENCES}

1. Okoye EI, Onyekweli1 AO, Kunle OO, Arhewoh MI. Brittle fracture index $(\mathrm{BFI})$ as a tool in the classification, grouping and ranking of some binders used in tablet formulation: Lactose tablets. Sci Res Essays 2010; 5: 500-6.

2. Onyekweli AO, Kunle OO, Okoye EI. Application of a newly developed multifunctional excipient in tablet formulation. Res J Pharm Tech 2013; 6:1019-31.

3. Adebayo AH, Abolaji AO, Kela R, Ayepola OO, Olorunfemi TB, Taiwo OS. Antioxidant activities of the leaves of
Chrysophyllum albidum G. Pak J Pharm Sci 2011; 24: 545-51.

4. Ige MM, Gbadamosi SO. Chemical composition and physicalproperties of african star apple (Chrysophyllum Albidum). Asset Series A 2007; 7: 37-42.

5. Farmers seek effective utilisation of agbalumo. http:// dailyindependentnig.com/2015/04/farmers-seek-effectiveutilisation-agbalumo/ (Accessed: $9^{\text {th }}$ September, 2015)

6. African star apple. http://www.harvestmall.com/afsa.html. (Accessed: $9^{\text {th }}$ September, 2015).

7. Bhosale RR, Osmani RAM, Padmaja C, Moin A. Formulation 
and evaluation of sustained release dosage form using modified cashew gum. Int J Pharm Pharm Sci 2015; 7:141-50.

8. Oforikwakye K, Asantewaa Y, Kipo SL. Physicochemical and binding properties of cashew tree gum in metronidazole tablet formulations. Int J Pharm Pharm Sci 2010; 2:105-9.

9. Kumar A, Uma AR, Gopal M, Moin A. Development of cashew gum and its derivatives for sustained released drug delivery system: by response surface methodology. Int J Pharm Pharm Sci 2014; 6: 476-84.

10. Okoye EI, Onyekweli AO, Ohwoavworhua FO, Kunle OO. Comparative study of some mechanical and release properties of paracetamol tablets formulated with cashew tree gum, povidone and gelatin as binders. Afri J Biotech 2009; 8:3970-3.

11. Okoye EI, Onyekweli AO, Fatoki OO. Evaluation of $\mathrm{LD}_{50}$ of cashew gum and the comparative study of its functionality in cotrimoxazole granule and tablet formulations. British J Pharmacol Toxicol 2012; 3:156-64.

12. Ofori-Kwakye K, Mfoafo KA, Kipo SL, Kuntworbe N, BoakyeGyasi ME. Development and evaluation of natural gum-based extended release matrix tablets of two model drugs of different water solubilities by direct compression. Saudi Pharm J 2016;24:82-91.

13. Badwan AA, Rashid I, Al Omari MMH, Darras FH. Chitin and chitosan as direct compression excipients in pharmaceutical applications. Mar Drugs 2015; 13:1519-47.

14. Ciprofloxacin Hydrochloride. http://www.Fda. Gov/Downloads/Drugs/Emergencypreparedness/ Bioterrorismanddrugpreparedness/Ucm 130802.Pdf. (Accessed: 24 ${ }^{\text {th }}$ September 2015).

15. Oliphant CM, Green GM. Quinolones: A comprehensive review. Am Fam Physician 2002; 65: 455-64.

16. Fahmy R, Kona R, Dandu R, Xie W, Claycamp G, Hoag SW. Quality by Design I: Application of Failure Mode Effect Analysis (FMEA) and Plackett-Burman Design of Experiments in the Identification of "Main Factors" in the Formulation and Process Design Space for Roller-Compacted Ciprofloxacin Hydrochloride Immediate-Release Tablets. AAPS PharmSciTech 2012; 13:1243-54.

17. Gaikwad VD, Yadav VD, Gaikwad MD. Novel sustained release and swellable gastroretentive dosage form for ciprofloxacin hydrochloride. Int J Pharm Investig 2014; 4: 88-92.

18. Arza ANK, Gonugunta CSR, Veerareddy PR. Formulation and Evaluation of Swellable and Floating Gastroretentive Ciprofloxacin Hydrochloride Tablets. AAPS PharmSciTech 2009; 10:220-6.

19. British Pharmaceutical Codex, $11^{\text {th }}$ Edition. The Pharmaceutical Press, London. 1979, pp 510.

20. Okoye EI, Onyekweli AO, Kunle OO. Solid state characterization of Anacardium occidentale gum. Res J Appl Sci Engin Techn 2012; 4: 3709-16.

21. Okoye EI, Awotunde T, Morales T. Comparative study of the functionality of povidone, gelatin and corn starch on Moringa oleifera leaf granule and capsule formulations. Am J Pharmtech Res 2013; 3:1-22.

22. British Pharmacopoeia, Volume 4. Her Majesty Stationery Office, London. 2009, pp A449
23. The International Pharmacopoeia Fifth Edition, 2015. Http:// Apps.Who.Int/Phint/En/P/Docf/. (Accessed 5th October 2015).

24. Alebiowu G, Itiola OA. Effects of starches on the mechanical properties of paracetamol tablet formulations. II. Sorghum and plantain starches as disintegrants. Acta Pharma 2003; 53:313-20.

25. Amid BT, Mirhosseini H. Effect of different purification techniques on the characteristics of heteropolysaccharideprotein biopolymer from durian (Durio zibethinus) seed. Molecules 2012; 17:10875-92.

26. Cunha PLR, De Paula RCM, Feitosa JPA. Purification of guar gum for biological applications. Int J Biol Macromol 2007; 41: 324-31.

27. Powder flow. http://www.pharmacopeia.Cn/V29240/ Usp29nf24s0_C1174.Html. (Accessed 20th December 2015).

28. Niklas S, Reiche K, Heinämäki J, Yliruusi J. Effect of moisture on powder flow properties of theophylline. Pharmaceutics 2010; 2: 275-90.

29. Meeus L. Direct compression versus granulation. Pharm Technol Europe 2011; 23:1-2.

30. Miinea LA, Mehta R, Kallam M, Farina JA, Deorkar N. Evaluation and characteristics of a new direct compression performance excipient. Pharm Technol 2011; 35:1-8.

31. Evelghem JV. Improving Tablet Quality with Compression to Equal Force Technology. Pharm Technol 2008. http://www. pharmtech.com/improving-tablet-quality-compressionequal-force-technology. (Accessed 4th March 2016)

32. Rudnic EM, Schwartz JB. Oral solid dosage forms. In: The science and Practice of Pharmacy $21^{\text {st }}$ Ed. Lppincott Williams and Wilkins, Philadelphia USA. 2006, pp 917.

33. British Pharmacopoeia Vol. 4. Her Majesty Stationery Office, London. 2003, pp 2051.

34. Uniformity of mass for single-dose preparations. The International Pharmacopoeia $-5^{\text {th }}$ Edition, 2015. Http://Apps. Who.Int/Phint/Pdf/B/Jb.7.5.3.Pdf. (Accessed 11th December 2015).

35. Lawal MV, Odeniyi MA, Itiola OA. Effect of thermal and chemical modifications on the mechanical and release properties of paracetamol tablet formulations containing corn, cassava and sweet potato starches as filler-binders. Asian Pac J Trop Biomed 2015; 5: 585-90.

36. Alebiowu G, Adebolu AA. Disintegrant properties of paracetamol tablet formulation lubricated with co - processed lubricants. Farmacia 2009; 57: 500-10.

37. USP monograph on ciprofloxacin hydrochloride tablet. http:// www.pharmacopeia.cn/v29240/usp29nf24s0_m17880.html. (Accessed 13th November 2015).

38. Okoye EI. Improvement of the crystal stability and dissolution profile of metronidazole by composite formation with microcrystalline cellulose and cashew gum. J Pharm Allied Sci 2014;11: 2006-26.

39. Avachat AM, Nandare DS. Effect of alcohol on drug release kinetics from hpmc-based matrix tablets using model drugs. Dissol Technol 2014; February: 11-17. 